Indonesian Journal for Social Responsibility (IJSR) Vol. 3, No. 02, (2021), hal. 83-94

\title{
DAKWAH DAN PEMBERDAYAAN: STRATEGI PENGEMBANGAN MASYARAKAT ISLAM MELALUI KOMUNITAS TASAWUF UNDERGROUND TERHADAP ANAK PUNK DAN ANAK JALANAN
}

\author{
Nur Hana Putri Nabila \\ Program Studi Pengembangan Masyarakat Islam, Fakultas Dakwah dan IImu Komunikasi, \\ Universitas Islam Negeri (UIN) Syarif Hidayatullah Jakarta, Indonesia \\ E-mail: hana.putri19@mhs.uijkt.ac.id \\ Received: April 26, 2021 / Revised: July 30, 2021 / Accepted: August 23, 2021 \\ DOI: https://doi.org/10.36782/ijsr.v3i2.81
}

\begin{abstract}
ABSTRAK
Dakwah memiliki fungsi dan peranan yang sangat besar pada seluruh aspek kehidupan manusia. Dakwah dalam pengembangan masyarakat Islam sebagai salah satu bentuk dakwah bilhal dengan proses dan kegiatan yang mengarah pada kesejahteraan masyarakat. Dakwah berupaya untuk meningkatkan kesadaran dari perilaku tidak baik dan menanamkan amar ma'ruf nahi munkar pada masyarakat. Salah satu penerapan dakwah dalam pengembangan masyarakat Islam, yakni melalui sebuah komunitas Tasawuf Underground. Pada kenyataannya, belum banyak juru dakwah ataupun ahli agama yang mampu hadir di antara anak punk dan anak jalanan. Selain itu, berdakwah pun tidak cukup hanya mengajarkan pendidikan agama, melainkan juga pemberdayaan ekonomi dan sosial agar anak punk dan anak jalanan dapat berhijrah secara total. Oleh karena itu, metode pengabdian yang digunakan adalah field research dengan pendekatan deskriptif kualitatif. Data yang bersumber dari data primer dan data sekunder. Hasil pengabdian terdapat perubahan secara signifikan pada anak punk dan anak jalanan setelah dididik melalui komunitas Tasawuf Underground.
\end{abstract}

Kata kunci: Anak Punk dan Anak Jalanan, Dakwah, Komunitas, Pemberdayaan, Pengembangan Masyarakat.

\begin{abstract}
Da'wah has a very large function and role in all aspects of human life. Da'wah in the development of Islamic society as a form of da'wah bilhal with processes and activities that lead to the welfare of the community. Da'wah seeks to raise awareness of bad behaviour and instill charity ma'ruf nahi munkar in society. One of the applications of da'wah in the development of Islamic society through an Underground Tasawuf community. In fact, there are not many preachers or religious experts who are capable of being present among punk and street children. In addition, preaching is not enough to only teach religious education, but also economic and social empowerment so that punk and street children can emigrate totally. Therefore, the type of research used is field research with a qualitative descriptive approach. Data sourced from primary data and secondary data. The result of this research is that there is a significant change in punk and street children after being educated through the Underground Tasawuf community.
\end{abstract}


Keywords: Community, Community Development, Da'wah, Empowerment, Punk Children and Street Children.

\section{PENDAHULUAN}

Dakwah pada hakikatnya adalah mengimplementasikan ajaran dan nilai-nilai Islam ke dalam kehidupan sehari-hari baik dalam lingkup pribadi, keluarga, maupun masyarakat sehingga terwujudnya khairu ummah yang sejahtera lahir batin, bahagia dunia, dan akhirat (Susanto, 2013). Dakwah berarti proses mengaktualisasikan baik dilakukan secara individu, kelompok, maupun sebuah komunitas pemberdayaan. Ada pula lembaga yang menetapkan sasaran, tujuan, bentuk kegiatan, dan langkah-langkah sistematis dalam proses kegiatan. Hal tersebut untuk mencapai tujuan dakwah itu sendiri secara efektif, optimal, dan efisien.

Islam merupakan agama dakwah, di mana konsep dari dakwah itu sendiri terdapat usaha untuk menyebarluaskan kepada umat manusia terkait kebenaran serta ajaran yang diyakini berasal dari Allah SWT. Semangat menyebarluaskan kebenaran tersebut merupakan tugas mulia dan wujud pengabdian kepada Allah SWT. Dengan melaksanakan dakwah (menegakkan amar ma'ruf nahi munkar) merupakan kewajiban semua umat Islam baik laki-laki maupun perempuan.

Dalam strategi dakwah, realitanya terdapat jenis dan pola yang bermacam-macam. Diantaranya strategi dakwah yang digunakan oleh para da'i adalah dakwah pemberdayaan masyarakat Islam.

Dakwah pemberdayaan sama dengan gerakan dakwah menuju transformasi sosial, yakni dakwah yang dijabarkan dalam gerakan pembebasan dari eksploitasi, dominasi, penindasan, serta ketidakadilan dalam berbagai aspeknya. Dari gerakan ini lahir dan membentuk masyarakat yang memiliki kecanggihan sosial (Puteh \& Saifullah, 2006). Jika dikorelasikan lebih detail dengan teori tersebut, dakwah pemberdayaan masyarakat lebih mengutamakan aksi daripada wacana atau retorika (tabligh). Gerakan dakwah pemberdayaan biasanya menjurus ke dalam lembaga-lembaga swadaya masyarakat muslim yang bebas dari gerakan politik masif. Dakwah pemberdayaan biasanya bergerak dalam bidang-bidang sosial, ekonomi, dan pendidikan (Ismail \& Hotman, 2011).

Pengembangan masyarakat Islam bertujuan untuk mengembangkan sebuah potensi umat dari yang kurang baik menjadi terasah dan meningkatkan ke arah yang lebih baik. Dalam sebuah proses pengembangan pun memiliki arah dan jalannya masing-masing baik berupa pengembangan ekonomi, pengembangan keterampilan, dan pengembangan ilmu pengetahuan. Hal itu dapat disesuaikan dengan situasi dan kondisi masyarakat serta potensi yang dimiliki oleh seorang da'i. Tujuan dari 
pengembangan masyarakat adalah pemberdayaan masyarakat dan peningkatan kualitas hidup manusia. Pemberdayaan berarti mengembangkan kekuatan dan kemampuan, potensi yang ada, dan sumber daya manusia agar mampu membela dirinya sendiri baik untuk sekarang, maupun di masa yang akan datang (Muslim, 2012).

Secara sistematis, pengembangan masyarakat Islam memiliki arah dan tujuan, yaitu: 1. Menganalisis problematika sosial secara umum dan keagamaan secara khusus yang muncul dalam kehidupan masyarakat sebagai akibat adanya perubahan sosial.

2. Merancang kegiatan pengembangan masyarakat berdasarkan masalah yang ada di masyarakat berdasarkan skala prioritas.

3. Mengelola dan melaksanakan kegiatan pengembangan masyarakat berdasarkan rencana yang disepakati (kemampuan menjadi pendamping)

4. Mengevaluasi seluruh proses pengembangan masyarakat (evaluasi pendampingan)

5. Melatih masyarakat dalam menganalisis masalah yang mereka hadapi, merancang, mengelola, serta mengevaluasi kegiatan pengembangan masyarakat (pelatihan pendampingan) (Ritonga, 2015).

Pada kenyataannya, belum banyak juru dakwah ataupun ahli agama yang mampu hadir di antara anak punk dan anak jalanan untuk memberdayakan mereka. Anak punk dan anak jalanan sering kali mendapat stigma buruk oleh

masyarakat. Dianggap kriminal, berpenampilan tidak seperti orang normal pada umumnya, pemakai narkoba dan psikotropika, dan sebagainya sehingga hal tersebut meresahkan masyarakat.

Departemen Sosial Republik Indonesia mendefinisikan anak jalanan adalah anak yang sebagian besar menghabiskan waktunya untuk mencari nafkah, berkeliaran di jalanan atau tempat umum lainnya. UNICEF memberikan batasan tentang anak jalanan, yaitu anak-anak berumur dibawah 16 tahun yang sudah melepaskan diri dari keluarga, sekolah dan lingkungan masyarakat terdekatnya, larut dalam kehidupan yang berpindah-pindah di jalan raya (Rido \& Suyanto, 2015).

Anak punk dan anak jalanan sebenarnya memiliki perbedaan. Beberapa masyarakat awam berpikir anak punk adalah anak jalanan. Akan tetapi, punk merupakan sebuah gaya hidup dan pilihan dimana mereka memiliki banyak definisi, seperti anak punk memiliki gaya identik yang hanya sebatas gaya berbusana saja, punk aliran musik, dan punk yang hanya mengikuti tanpa mengetahui makna yang sebenarnya dari punk itu sendiri. Hal tersebut yang membuat nama punk menjadi negatif di lingkungan masyarakat. Anak punk biasanya sangat tidak membatasi hidupnya mamun menuntut dirinya untuk berkreasi tanpa batas dan sesuai keinginan mereka sendiri tanpa paksaan dari siapapun (Fahreza, 2017). 
Di dalam pemberdayaan masyarakat yang diselenggarakan melalui sebuah komunitas merupakan salah satu bagian penting dalam pengembangan masyarakat Islam. Terutama pada anak punk dan anak jalanan. Bahkan keduanya menjadi bagian yang sangat penting untuk diberdayakan. Permasalahan yang akan dibahas adalah mengapa harus mengutamakan anak punk dan anak jalanan? Bagaimana dakwah dan pemberdayaan diterapkan pada anak punk dan jalanan? Adapun tujuannya adalah mengetahui peranan penting dan implementasi program pemberdayaan masyarakat pada komunitas Tasawuf Underground, serta mengetahui perubahan pada anggota komunitas di dalamnya.

\section{METODOLOGI}

\section{A. Pendekatan Pengabdian}

Tujuan pengabdian ini adalah pengabdian deskriptif, yaitu menyajikan gambaran yang secara spesifik atau hubungan dengan terperinci. Selain itu, menemukan data baru yang bertentangan dengan data lama, menciptakan serangkaian kategori atau mengklasifikasi jenis, menjelaskan rangkaian tahapan atau langkah, mendokumentasi proses atau mekanisme sebab akibat dan melaporkan latar belakang atau konteks situasi (Lawrence, 2013).

Bertato, rambut gondrong, celana ketat, dan piercing sebuah penampilan yang identik dengan anak punk jalanan. Namun, faktor penampilan tersebut tidak menghalangi niat mereka untuk belajar ilmu agama Islam dan mengamalkan nilainilai kebaikan.

Pengabdian ini adalah jenis pengabdian lapangan field research, yaitu pengabdian dalam pengumpulan datanya dilakukan di lapangan, yakni di Tasawuf Underground. Pengabdian ini merupakan pengabdian kualitatif, yakni suatu pengabdian yang bertujuan untuk menerangkan fenomena sosial atau suatu peristiwa.

Hal ini sesuai dengan definisi pengabdian kualitatif yaitu suatu pengabdian yang menghasilkan data deskriptif berupa kata-kata tertulis atau lisan dari orang-orang dan dari perilaku yang dapat diamati (Moleong, 2008).

\section{B. Subjek Pengabdian}

Subjek pada pengabdian ini, yakni pendiri Tasawuf Underground, yaitu Ustad Halim Ambiya, anak punk, dan anak jalanan yang telah menetap di Tasawuf Underground. Dalam mengambil data, penulis mengadakan pengamatan lapangan. Berdasarkan ruang lingkup permasalahan yang diuraikan diatas, maka lokasi yang dipilih untuk diteliti adalah Komplek Ruko Ciputat, Jl. RE Martadinata No. 27, Ciputat, Tangerang Selatan, Banten 15411. Pemilihan tempat ini didasarkan pada titik kumpul kegiatan Komunitas Tasawuf Underground bersama anak punk dan anak jalanan.

\section{Sumber Pengabdian}

Berdasarkan manfaat dari pengambilan data secara empiris, metode pengumpulan data kualitatif secara observasi merupakan yang paling tepat terhadap semua metode 
pengumpulan data. Teknis analisis data yang dilakukan, yakni dengan metode wawancara mendalam, observasi partisipasi, bahan dokumenter, serta metode-metode baru seperti metode bahan visual dan metode penelusuran bahan internet (Bungin, 2015). Dalam memilih metode, penulis memilih ketiga metode tersebut karena sesuai dengan kebutuhan di lapangan.

\section{Sumber Data}

Sumber data dalam pengabdian ini menggunakan dua macam data, yaitu data primer dan sekunder.

1. Data primer, yaitu data yang diperoleh langsung oleh penulis dari sumber informasi pertama. Adapun yang menjadi sumber data primer dalam pengabdian ini adalah pendiri Tasawuf Underground, Ustad Halim Ambiya, anak punk, dan anak jalanan yang sudah menetap di Tasawuf Underground.

Selain itu, penulis menggunakan metode wawancara. Wawancara mendalam secara umum adalah proses memperoleh keterangan untuk tujuan pengabdian dengan cara tanya jawab sambil bertatap muka antara pewawancara dan informan atau orang yang diwawancarai, dengan atau tanpa menggunakan pedoman (guide) wawancara, di mana pewawancara dan informan terlibat dalam kehidupan sosial yang relatif lama. Dengan demikian, kekhasan wawancara mendalam adalah keterlibatannya dalam kehidupan informan (Bungin, 2015).
2. Data sekunder, yaitu data yang langsung dikumpulkan oleh penulis sebagai penunjang dari sumber pertama. Dalam pengabdian yang penulis lakukan, berita, dan jurnal merupakan sumber data sekunder.

\section{HASIL DAN PEMBAHASAN}

\section{Latar Belakang dan Tujuan Komunitas Tasawuf Underground}

Komunitas merupakan sekumpulan anggota yang saling terhubung rasa saling memiliki dan terikat antara satu dengan lainnya. Selain itu, mereka percaya bahwa kebutuhan anggota pada sebuah komunitas itu sendiri akan lebih mudah terpenuhi jika para anggota saling berkomitmen untuk terus bersama-sama.

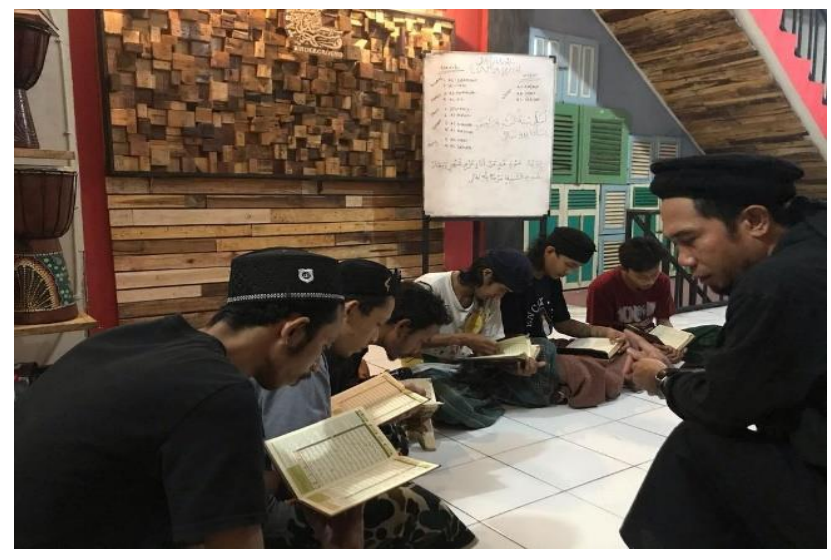

Gambar 1. Pendampingan Mengaji Anak Punk dan Anak Jalanan

(Sumber: Instagram Tasawuf Underground, 2021)

Pemberdayaan berbasis komunitas adalah sebuah langkah yang nyata bagi masyarakat dalam memenuhi kebutuhan mereka. Hal tersebut disebabkan masyarakat secara tidak langsung dapat memberdayakan diri mereka sendiri tanpa ada tekanan atau intervensi dari pihak eksternal. Dengan kata lain, 
pemberdayaan berbasis komunitas lebih mengedepankan pada kearifan lokal yang menunjukkan identitas dari komunitas itu sendiri (Ramadhani, 2020).

Kini, komunitas Tasawuf Underground berada di bawah pengelolaan Yayasan BahjatunNufus. SK Kemenkumham RI Nomor AHU0003650.AH.01.04 Tahun 2015. Komunitas anak muda ini sangat peduli terhadap nasib anak-anak punk dan jalanan di sekitar Jabodetabek. Mereka membutuhkan pendekatan secara khusus agar menjadi insan yang berguna bagi masyarakat dan lingkungannya.

Penulis memutuskan untuk mewawancarai pendiri Tasawuf Underground, Halim Ambiya dan salah satu santri, yakni Trian Nugraha sebagai informan. Berdasarkan observasi penulis akan melihat proses pemberdayaan dengan mendeskripsikan jawaban dari narasumber

\section{Latar Belakang Pendiri Tasawuf Underground Melakukan Pemberdayaan}

Tasawuf Underground merupakan komunitas pemberdayaan yang merangkul anakanak punk dan anak jalanan, serta berupaya untuk mendekatkan mereka dengan agama Islam. Selain itu, komunitas ini bertujuan untuk mengubah hidup mereka dengan berhijrah dan meningkatkan kesejahteran baik di dunia maupun akhirat. Dengan demikian, hadirnya komunitas ini diharapkan akan menjadikan wadah untuk memberikan pengetahuan tentang hijrah pun mengenalkan agama kepada mereka.
Berdakwah tak cukup mengajarkan pendidikan agama pada anak punk jalanan, melainkan juga pemberdayaan ekonomi dan sosial agar mereka dapat hijrah secara total. Oleh sebab itu, Tasawuf Underground memiliki program, yakni 'peta jalan pulang'. Pertama, jalan pulang kepada Allah, dan kedua, jalan pulang kepada orang tua.

\section{Memilih Anak Punk dan Anak Jalanan sebagai Target Proses Pemberdayaan}

Di dalam pemberdayaan masyarakat yang diselenggarakan melalui sebuah komunitas merupakan salah satu bagian penting dalam pengembangan masyarakat Islam. Terutama pada anak punk dan anak jalanan. Pertanyaan yang sering muncul adalah "Mengapa dalam dakwah pemberdayaan masyarakat komunitas Tasawuf Underground mengutamakan anak punk dan anak jalanan?"

Hasil analisis menyatakan bahwa pada kenyataannya, saat ini tidak banyak juru dakwah ataupun ahli agama yang mampu hadir di antara anak punk dan anak jalanan. Dengan demikian, hadirnya komunitas ini diharapkan akan menjadikan wadah untuk memberikan pengetahuan tentang hijrah pun mengenalkan agama kepada mereka.

\section{Hal Sulit dalam Proses Pemberdayaan Terhadap Anak Punk dan Anak Jalan}

Kenyataannya dalam melakukan proses pemberdayaan tidak selalu berjalan mulus. 
Seringkali terdapat hal sulit dalam prosesnya. Salah satunya, yaitu melatih mereka disiplin untuk mengubah mindset dan kebiasaan anak jalanan. Menurut Halim untuk menjalani kehidupan normal harus melalui pendidikan pondok pesantren agar pemberdayaan berhasil.

\section{Kesan Anak Punk dan Anak Jalanan Terkait}

\section{Pemberdayaan Ekonomi}

Salah satu murid Tasawuf Underground, Trian Anugerah Permana alias Pongky, merasakan dampak yang signifikan dengan adanya pemberdayaan ekonomi dan sosial. la merasa punya tanggung jawab, lebih bisa manage waktu, dan memiliki lebih banyak pengalaman. Tak hanya di jalanan dan lampu merah, melainkan berwirausaha. Dengan adanya ia di Tasawuf Underground, menurutnya, lebih punya arah dan tujuan.

\section{Perubahan Signifikan Terhadap Anak Punk dan Anak Jalanan}

Trian Nugraha kini sudah dapat berkuliah mengambil jenjang S1. Dahulu ia hanya mengamen dan melakukan aktivitas sebagai anak punk jalanan. Selain itu, anak punk dan anak jalanan yang menetap di komunitas tersebut sudah mulai meninggalkan dan jauh dari zat adiktif, narkoba, dan psikotropika. Mereka sudah dapat membaca Al-Qur'an, salat 5 waktu dan sunah, zikir, menulis Al-Qur’an.

Implementasi Program Pemberdayaan Anak Punk dan Anak Jalanan
Komunitas Tasawuf Underground merupakan suatu perkumpulan yang melaksanakan kegiatan pemberdayaan kreativitas. Komunitas ini juga memiliki tujuan untuk mengumpulkan orang-orang yang mempunyai satu pemikiran untuk menyalurkan aspirasi.

Tabel 1. Data Anak Punk dan Anak Jalanan yang Dibina di Tasawuf Underground

\begin{tabular}{ccc}
\hline Tahun & $\begin{array}{c}\text { Tersentral di } \\
\text { Pondok } \\
\text { Tasawuf } \\
\text { Underground }\end{array}$ & Menyebar \\
\hline 2016 & - & 18 orang \\
\hline 2017 & - & 38 orang \\
\hline 2018 & 8 orang & 76 orang \\
\hline 2019 & 16 orang & 104 orang \\
\hline 2020 & 24 orang & 146 orang \\
\hline 2021 & 26 orang & 290 orang \\
\hline
\end{tabular}

Masalah yang sering kita jumpai, banyak anak punk dan anak jalanan yang memiliki bermacam-macam bakat, tetapi tidak ada wadah untuk mengasah dan menyalurkan bakat tersebut. Dengan demikian, dibutuhkan proses pemberdayaan masyarakat melalui pendidikan nonformal.

Kegiatan ini sebagai upaya untuk memungkinkan kapasitas masyarakat lebih aktif dan partisipatif. Dengan segala kemampuan yang dapat memberdayakan diri sendiri, pusat aktivitas, dan dilaksanakan serta memberi dampak kepada masyarakat. Istilah lain adalah pendidikan berbasis masyarakat (Soedarwo, 2017). 
Pada awalnya, komunitas ini hanya dibentuk untuk belajar ilmu tasawuf melalui media sosial. Lambat laun, pengajian tasawuf pun mulai berkembang dari kafe ke kafe. Sejak 2016, komunitas ini berdakwah di tengah kaum marjinal, khususnya pembinaan anak-anak punk dan jalanan.

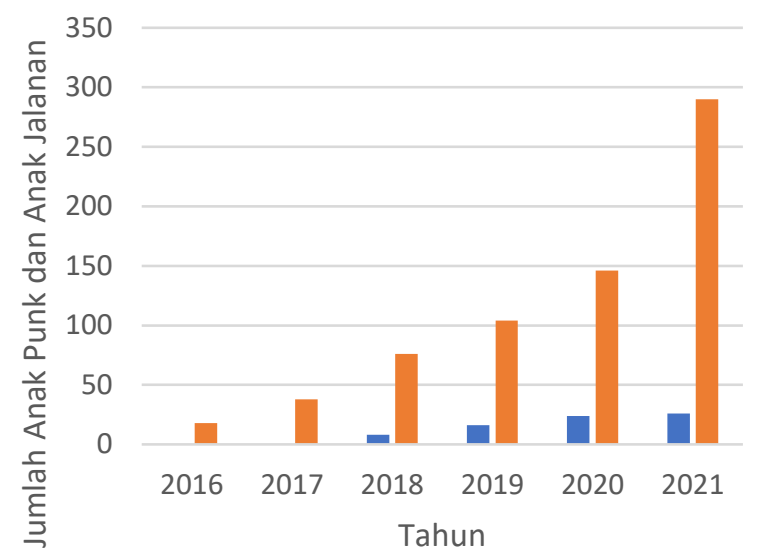

- Tersentral di Pondok Tasawuf Underground - Menyebar

Grafik 1. Peningkatan Anak Punk dan Anak Jalanan Tiap Tahun

Dipelopori oleh Halim Ambiya, Tasawuf Underground sudah meluas dan berdakwah di pasar, terminal, stasiun, kolong jembatan, dan tempat-tempat kaum marjinal berkumpul di Jabodetabek. Kini, Tasawuf Underground terpusat dan berlokasi di Komplek Ruko Ciputat, Jl. RE Martadinata No. 27, Ciputat, Tangerang Selatan, Banten 15411.

Latar belakang Tasawuf Underground didirikan yakni untuk mengimplementasikan pemberdayaan masyarakat dengan mengenalkan konsep "Peta Jalan Pulang" pada anak punk dan jalanan. "Peta Jalan Pulang" terbagi menjadi dua: Pertama, jalan pulang kepada Allah, dan kedua, jalan pulang kepada keluarga.

Pertama, melalui program peta jalan pulang kepada Allah. Komunitas ini mengajarkan terkait pendidikan agama Islam melalui salat, baca tulis Al-Qur'an, puasa sunah, zikir, dan pengajian keislaman layaknya pesantren, yakni dengan membaca kitab. Pendidikan dan hidup layaknya pesantren.

Hal itu perlu dilakukan agar mereka dapat menjalani kehidupan normal, melatih mereka disiplin, mengubah pola pikir dan kebiasaan hidup anak punk dan jalanan. Tujuan utama nya agar mereka tahu jalan pulang kepada Allah dan akhirat, serta melepaskan anak-anak punk jalanan dari kecanduan narkoba, psikotropika, dan zat adiktif lainnya.

Kedua, konsep peta jalan pulang kepada orang tua adalah dengan cara memberdayakan anak punk dan anak jalanan secara sosial dan ekonomi agar mereka kembali meraih mimpi dan harapan. Saat ini, komunitas Tasawuf Underground telah memberdayakan anak punk dan jalanan melalui enam program, yakni:

\section{Pendidikan Pondok Pesantren}

Pengajian rutin (baca tulis Al-Quran, kajian IImu Fiqih dan Tasawuf), Terapi Inabah (Hidroterapi, Dzikir dan Konseling), pengajian kitab (Kitab Al-Hikam Syekh Ibnu Atha'illah, Kitab Nashaihul 'Ibad Syekh Nawawi Al-Bantani, Kitab Al-Mawaizh karya Imam Al-Ghazali, Kitab SirrulAsrar karya Syekh Abdul Qadir Al-Jailani, Kitab 
Bulughul Maram, Kitab Al-Jurumiyah, Kitab Safinatun-Najah, Kitab Riyadhushalihin, Kitab Aqidatul Awam, dan Kitab Nurul-Yaqiin).
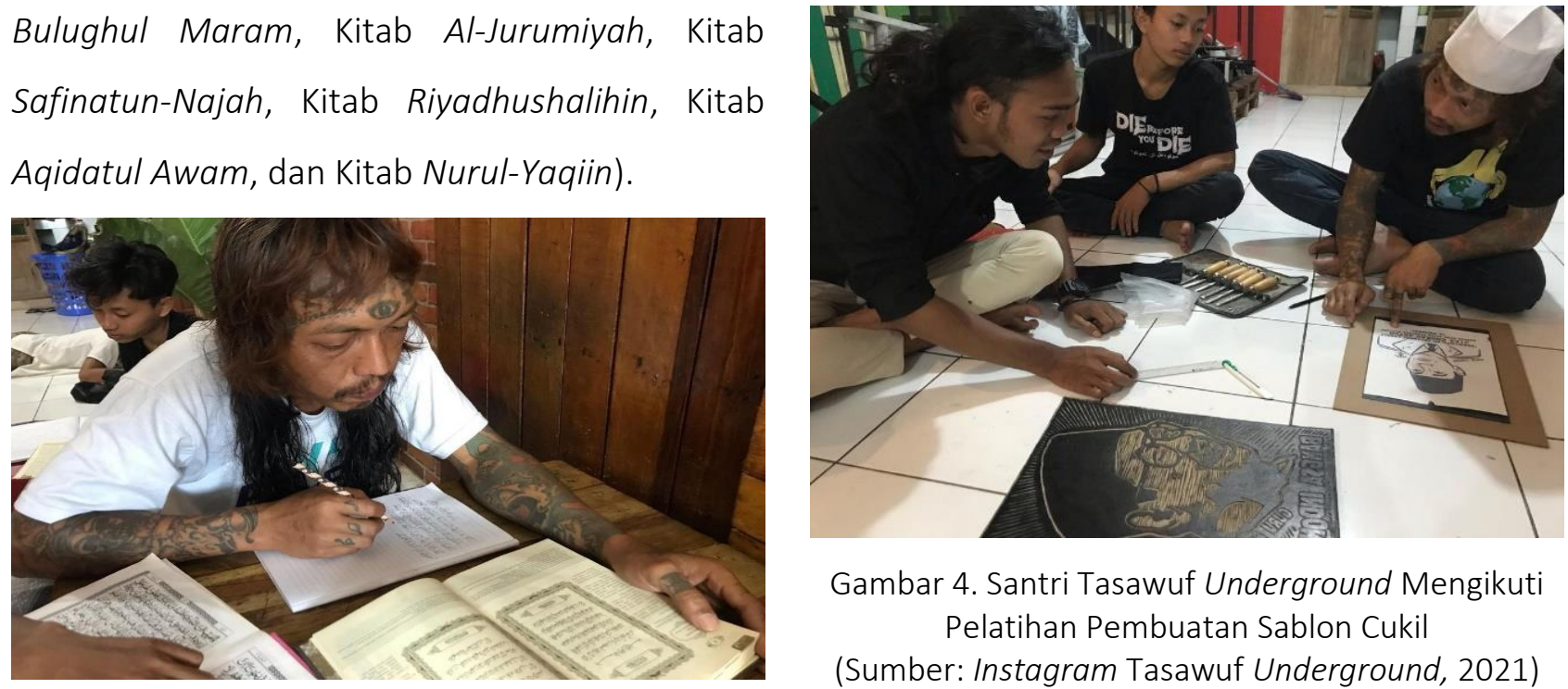

Gambar 4. Santri Tasawuf Underground Mengikuti Pelatihan Pembuatan Sablon Cukil

(Sumber: Instagram Tasawuf Underground, 2021)

Gambar 2. Belajar Baca dan Tulis Al-Qur'an (Sumber: Instagram Tasawuf Underground, 2021)
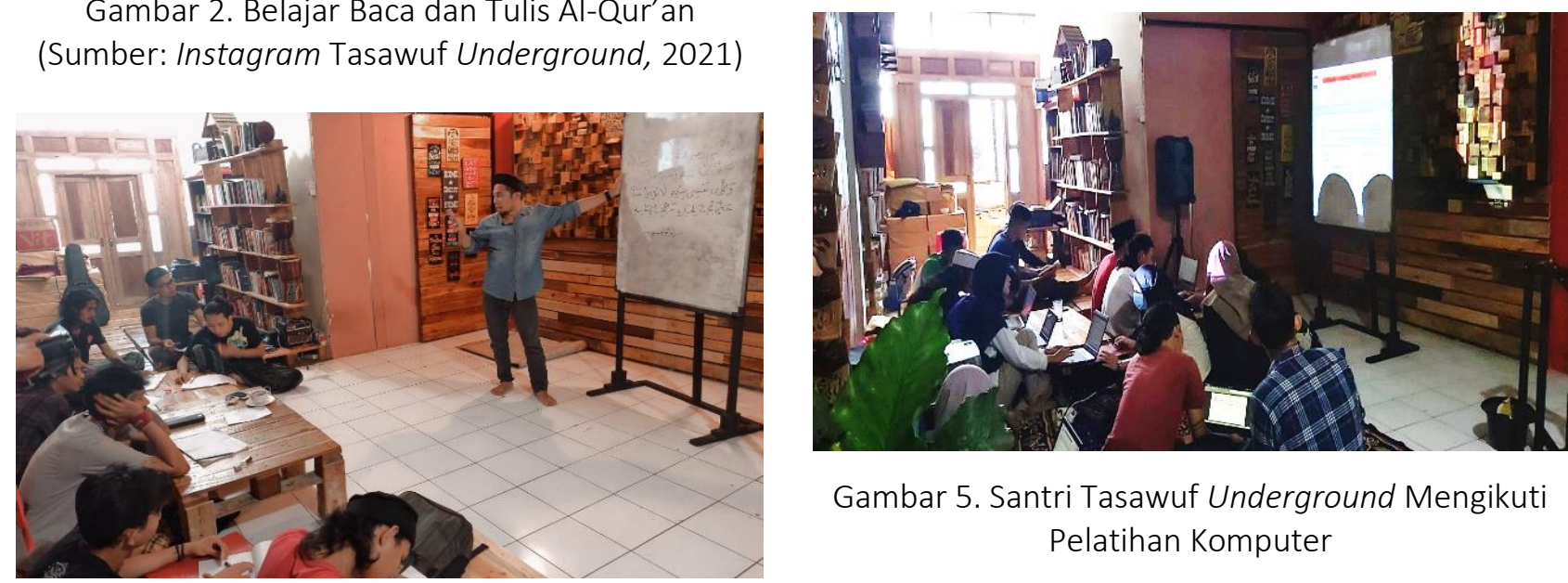

Gambar 5. Santri Tasawuf Underground Mengikuti Pelatihan Komputer

Gambar 3. Suasana Pembelajaran Pendidikan Agama Islam

(Sumber: Instagram Tasawuf Underground, 2021)

\section{Pemberdayaan Sosial dan Ekonomi}

Program Paket A, B dan C bagi yang anak punk dan jalanan yang putus sekolah. Komunitas Tasawuf Underground terdapat program pendidikan agama Islam, bimbingan konseling, serta terapi anti narkoba. Selain itu, komunitas ini pun menyediakan pelatihan-pelatihan, seperti pelatihan barista, sablon digital dan sablon cukil, pangkas rambut, komputer, percetakan, desain

\section{Angkringan}

Dalam proses pemberdayaan, tidak dapat dipaksakan bahwa masing-masing anak punk jalanan dididik pada lini usaha yang sama. Apabila mereka tidak dapat bekerja sebagai karyawan, maka komunitas ini mengajarkan mereka sebagai pengusaha, yakni dengan membuka usaha angkringan dan 7 gerobak usaha lainnya, seperti gorengan, pecel ayam, cendol dawet, es buah, sablon digital, dan lainlain. grafis, dan bisnis online. 


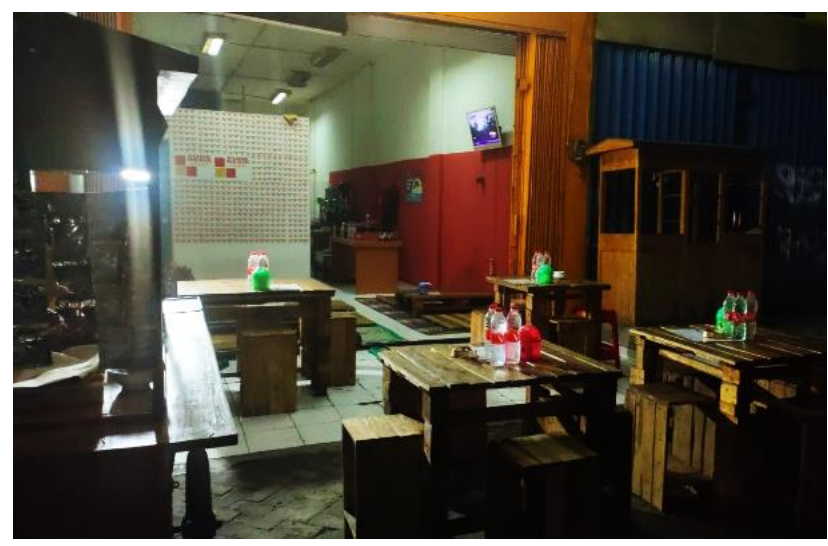

Gambar 6. Membuka Usaha Angkringan

Pemberdayaan masyarakat merupakan sebuah proses dalam bingkai usaha memperkuat esensi dari community self reliance atau kemandirian. Dalam proses ini masyarakat didampingi untuk membuat analisis masalah yang dihadapi, dibantu untuk menemukan alternatif masalah tersebut, serta diperlihatkan strategi memanfaatkan berbagai resources yang dimiliki dan dikuasai. Dalam proses itu masyarakat dibantu bagaimana merancang sebuah kegiatan sesuai dengan kemampuan yang dimiliki, bagaimana mengimplementasikan rancangan tersebut, serta bagaimana membangun strategi memperoleh sumbersumber eksternal yang dibutuhkan sehingga memperoleh hasil optimal (Huraerah, 2008).

Konsep "Peta Jalan Pulang" yang diimplementasikan pada anak punk dan anak jalanan sangat memberikan dampak secara signifikan. Dalam proses pemberdayaan masyarakat, mereka didampingi, dibantu dan diberikan wadah untuk menemukan jalan keluar dari masalah mereka. Dampak positif pemberdayaan pada komunitas ini sangat nyata.
Salah satunya, santri Tasawuf Underground, Trian Nugraha kini sudah dapat berkuliah mengambil jenjang S1. Dahulu ia hanya mengamen dan melakukan aktivitas sebagai anak punk jalanan. Selain itu, anak punk dan anak jalanan yang menetap di komunitas tersebut sudah mulai meninggalkan dan jauh dari zat adiktif, narkoba, dan psikotropika. Mereka sudah dapat membaca Al-Qur'an, salat 5 waktu dan sunah, zikir, menulis Al-Qur'an.

Pendiri Tasawuf Underground, Ustad Halim Ambiya pun berhasil pula memberdayakan salah satu anak punk yang awalnya bekerja sebagai tukang tato bagi anak punk dan anak jalanan. Setelah dididik dibawah komunitas ini, la sekarang bekerja sebagai desainer interior untuk kafe dan ruang pertemuan.

\section{KESIMPULAN}

Pendiri komunitas Tasawuf Underground mengaktualisasikan dakwah pemberdayaan masyarakat Islam lebih mengutamakan aksi nyata. Dakwah pemberdayaan tidak hanya pada pengetahuan ilmu agama, melainkan bergerak dalam bidang-bidang sosial, ekonomi, dan pendidikan. Konsep "Peta Jalan Pulang" yaitu jalan pulang kepada Allah dan jalan pulang kepada orang tua yang diimplementasikan kepada anak punk dan anak jalanan memiliki perubahan secara signifikan.

Anak punk dan anak jalanan sudah jauh dari narkoba, mabuk-mabukan, dan zat adiktif lainnya. Pemberdayaan masyarakat islam yang 
membantu mereka untuk menjalani hidup lebih baik dan mandiri sehingga mempunyai arah tujuan. Inilah pemberdayaan masyarakat Islam yang dapat dilihat secara nyata dan jelas sebagai perwujudan yang diterapkan "Peta Jalan Pulang" komunitas Tasawuf Underground.

\section{UCAPAN TERIMA KASIH}

Terima kasih kepada Allah SWT yang telah memberikan saya kelancaran dalam pengabdian ini. Ucapan terima kasih banyak pula kepada pendiri Komunitas Tasawuf Underground, yakni Ustad Halim Ambiya yang telah memberikan kesempatan kepada saya untuk berbagi ilmu dakwah dan pemberdayaan sekaligus cerita yang sangat menginspirasi. Terakhir, terima kasih kepada anak punk dan anak jalanan santri Komunitas Tasawuf Underground yang menyempatkan waktunya untuk berbagi kisah dan pengalamannya. Saya sangat beruntung karena telah mendapatkan kesempatan ini.

\section{DAFTAR PUSTAKA}

Bungin, M. B. (2015). Penelitian Kualitatif. Jakarta: Kencana Prenada Media.

Fahreza, V. (2017). Pemberdayaan Anak Punk oleh Komunitas Taring Babi melalui Kegiatan Daur Ulang Sampah [Skripsi]. Fakultas Dakwah dan IImu Komunikasi UIN Syarif Hidayatullah, Jakarta.

Huraerah, A. (2008). Pengorganisasian dan Pengembangan Masyarakat. Bandung: Humaniora.
Ismail, A. I., \& Hotman, P. (2011). Filsafat Dakwah Rekayasa Membangun Agama dan Peradaban. Jakarta: Kencana Prenada Media Grup.

Lawrence, N. W. (2013). Metodologi Penelitian Sosial: Pendekatan Kualitatif dan Kuantitatif. Jakarta: Indeks.

Moleong, L. J. (2008). Metode Penelitian Kualitatif. Bandung: Remaja Rosdakarya.

Muslim, A. (2012). Dasar-Dasar Pengembangan Masyarakat. Yogyakarta: Samudra Biru.

Puteh, M. J., \& Saifullah. (2006). Dakwah Tekstual dan Kontekstual Peran dan Fungsinya dalam Pemberdayaan Ekonomi Umat. Yogyakarta: AK Grup.

Ramadhani, T. (2020). Pemberdayaan Masyarakat Berbasis Komunitas Melalui Usaha Mikro Kecil Menengah (UMKM) (Studi Kasus Kelompok Pembuat Kritcu BaBe di Desa Batu Belubang). RESIPROKAL: Jurnal Riset Sosiologi Progresif Aktual, 2(2), 219228.

Rido, A. B. A., Suyanto, T. (2015). Aktivitas Komunitas Save Street Child dalam Pendidikan Moral Anak Jalanan di Daerah Lokalisasi Balungcangkring, Mojokerto. Jurnal Kajian Moral dan Kewarganegaraan, 2(3), 979-993.

Ritonga, A. (2015). Pengertian, Arah, dan Tujuan Dakwah dan Pemberdayaan Masyarakat. HIKMAH: Jurnal Ilmu Dakwah dan Komunikasi Islam, 2(2), 83-98. 
Soedarwo, V. S. D., Zuriah, N., Yuliati, R., Tasawuf Underground. (2021, April 8). IMAN Suwignyo. (2017). Pemberdayan TERGANTUNG KEBAIKANMU PADA Masyarakat Melalui Pendidikan Non-Formal TETANGGA [Foto Instagram]. Diakses dari Berbasis Potensi Lokal dalam Membangun https://www.instagram.com/p/CNaSWQkF Desa Wisata Adat. Jurnal Sosiologi Rcw/ Pendidikan Humanis, 2(2), 96-102.

Tasawuf Underground. (2021, April 16).

Susanto, D. (2013). Gerakan Dakwah Aktivis TADARUS AL-QUR'AN SANTRI Perempuan 'Aisyiyah Jawa Tengah. Journal UNDERGROUND [Foto Instagram]. Diakses of Islamic Studies and Humanities (JISH), 323-340. dari https://www.instagram.com/p/CNuxxB ZIJCA/

Tasawuf Underground. (2021, Maret 18). Moga Tasawuf Underground. (2021, April 22). SABLON istiqamah dan terus berjuang melawan rasa CUKIL UNDERGROUND [Foto Instagram]. malas [Foto Instagram]. Diakses dari Diakses dari https://www.instag https://www.instagram.com/p/CMjNGShFh ram.com/p/CN9wfsllTGP/ g-/ 